\section{Indirect Haemagglutination Test for Malarial Antibody}

Stein and Desowitz ${ }^{1-3}$ have used an indirect haemagglutination test for malarial antibody using tanned formolized sheep erythrocytes sensitized with an antigen prepared from erythrocytic malarial parasites released from the erythrocytes. The method of release was osmotic breakage in distilled water followed by grinding of the sediment. In our experience such a sediment is heavily contaminated with leucocyte and lymphocyte nuclear DNA and probably some other blood debris. Stein and Desowitz ${ }^{2,3}$ have published results which admit to false positive results with normal serum from zero to $1: 1,600$ dilution. Desowitz and Saave ${ }^{4}$ used the technique to determine antibody levels in a population in New Guinea exposed to hyperendemic malaria (enlarged spleen rates: 100 per cent in children, 35 per cent in adults). They reported results using $P$. coatneyi antigen which included a negative reaction in 22 per cent of the 7-15 year old age group, a reaction at a dilution of $1: 1,600$ in 28.5 per cent of the 1-2 year old age group, and an accretion of antibody of less than three-fold from infants to adults. These figures suggest to us that there was a significant amount of test failure and equally a significant amount of false positivity. Bray $^{5}$ reported difficulty in obtaining consistent results using tanned formolized cells and a purer antigen. We have since experienced failures with the technique reported satisfactorily by him. Two faults appear paramount; failure to bind antigen on to formolized cells and autoagglutination of formolized cells. On the other hand, agglutinins are certainly present in malaria serum.

Assuming the formolized sheep erythrocyte to be a poor vehicle for malarial antigen, attempts were made to sensitize unformolized cells and latex particles. Sheep erythrocytes were washed in physiological saline and used in the form of a 2 per cent suspension. Naked erythrocytes were either sensitized for $15 \mathrm{~min}$ at $37^{\circ} \mathrm{C}$ with an equal volume of a $1: 2,000$ solution of antigen in phos. phate buffered saline (PBS, $p H$ 7*2) or tanned by treatment for $15 \mathrm{~min}$ at $37^{\circ} \mathrm{C}$ with an equal volume of a $1: 20,000$ solution of tannic acid. The tanned cells were sensitized for $15 \mathrm{~min}$ at $37^{\circ} \mathrm{C}$ with an equal volume of a $1: 15,000$ solution of antigen in PBS. Antigen at a concentration of $1: 5,000$ or $1: 10,000$ is equally satisfactory. One drop of the sensitized erythrocyte suspension was added to the diluted sera. Antigen from $P$. berghei (strain NK65 from Katanga) and $P$. vinckei erythrocytic forms was obtained by the method of Spira and Zuckerman ${ }^{7}$ modified as follows. First, the washed parasitized blood was mixed with half its volume of 11 per cent dextran (molecular weight, $60,000-90,000$ ) in PBS and allowed to stand for I h to separate the white blood cells which were discarded in the supernatant as recommended by Spira (personal communication). Second, the released parasites were lyophilized, ground, extracted in water and the soluble extract lyophilized. The soluble dry product was used as antigen. Serum was obtained from normal rats, and from rats recovered from, and immune to, $P$. berghei (NK65), $P$. berghei ( $R C A$ strain from the République Centrafricaine), $P$. vinckei and $P$. chabaudi infection.

All sera were inactivated, absorbed on sheep erythrocytes and diluted for use. The diluent was 1 : 100 inactivated and absorbed normal rabbit serum in PBS. In addition latex particles were sensitized with a $1: 200$ solution of antigen by incubation for $2 \mathrm{~h}$ at $37^{\circ} \mathrm{C}$ and one drop of the sensitized particles was added directly to the serum dilution. All sera were also titrated for antibody using the fluorescent antibody technique.

The results of the indirect haemagglutination test are shown in Table 1 with the results of fluorescent antibody tests for comparison. The test gave negative results in all control conditions. Sera immune to $P$. vinckei and the related $P$. chabaudi gave largely negative results and appear to contain little or no agglutinins active in
Table 1. ReCiprocal of the Highest DHution at whiO the TeST was Positive

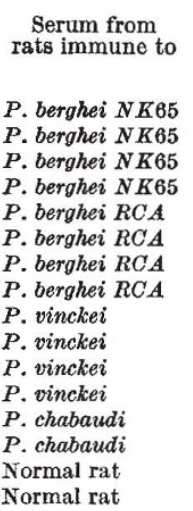

Indirect haemagglutination
tanned sheep erythrocytes
$P$. berghei $P$. vinckei
antigen

Fluorescent antibody technique $P$. berghei $P$. vinckei antigen antigen antigen antigen

$\begin{array}{rrrr}80 & 40 & 320 & 40 \\ 40 & 40 & 640 & 80 \\ 20 & <10 & 640 & 40 \\ 160 & 80 & 640 & 80 \\ 160 & 160 & 320 & 80 \\ 160 & 80 & 320 & 80 \\ 160 & 80 & 320 & 40 \\ 640 & 320 & 320 & 80 \\ <10 & <10 & 20 & 80 \\ <10 & <10 & 20 & 80 \\ <10 & <10 & 20 & 160 \\ <10 & <10 & 20 & 160 \\ 10 & <10 & 80 & 160 \\ <10 & <10 & 40 & 320 \\ <10 & <10 & <5 & <5 \\ <10 & <10 & <5 & <5\end{array}$

this test. Voller ${ }^{8}$ has reported that $P$. vincke $i$ is unsatisfactory in the fluorescent antibody test. Sensitized naked cells without tanning gave negative results throughout and little or no polysaccharide or lipopolysaccharide would seem to be involved in any agglutination reaction. Sensitized tanned cells gave satisfactory and reproducible results using serum immune to both strains of $P$. berghei and both parasite antigens. The two antigens gave similar results with the same serum and it would appear that $P$. berghei and $P$. vincke $i$ share common antigens active in the test. Sensitized latex particles gave unsatisfactory results with only weak positive results with very low dilutions of a few immune sera.

Careful formolization of sensitized tanned cells ${ }^{2}$ yielded cells which were satisfactory in the test provided no autoagglutination occurred. Some autoagglutination was a frequent occurrence, however, and the amount of autoagglutination varied with batches of erythrocytes. Small clumps increased the sensitivity of the test, giving higher positive dilutions of immune sera, but remained negative for control sera. Larger clumps in large numbers gave false positive results throughout. Sensitized tanned cells were particularly liable to autoagglutination, and subsequent freezing or lyophilizing invariably caused clumping. No conditions of preparation could prevent autoagglutination in the thawed material after freezing, and the clumps had to be broken by 5 min of disruption in a Waring blender ${ }^{10}$, after which they were sometimes satisfactory. If the formolized cells were placed in a Waring blender for $5 \mathrm{~min}$ before freezing or lyophilization and disrupted similarly after thawing or reconstitution they were usually satisfactory.

In summary, the indirect haemagglutination test using non-formolized but tanned erythrocytes detects antibody to $P$. berghei infection when either $P$. berghei or $P$. vinckei antigens are used to sensitize the erythrocytes. Serum immune to $P$. vinckei or $P$. chabaudi contains little or no antibody active in the test.

R. S. Bray

H. M. S. EL-NAHAL

Department of Parasitology,

London School of Hygiene and Tropical Medicine, Keppel Street, London, W.C.1.

${ }^{1}$ Stein, B., Unesco First Reg. Symp. Scient. Knowledge Trop. Parasitol., Univ. Singapore, 170 (1962).

z Desowitz, R. S., and Stein, B., Trans. Roy. Soc. Trop. Med. Hyg., 56, 257 (1962).

${ }^{3}$ Stein, B., and Desowitz, R. S., Bull. Wld. Hlth. Org., 30, 45 (1964).

- Desowitz, R, S., and Saave, J. J., Bull. Wld. Hlth. Org., 32, 149 (1965).

${ }^{5}$ Bray, R. S., Ann. Soc. Belge, Méd. Trop., 45, 397 (1965).

B Brown, K. N., and Brown, I. N., Nature, 208, 1286 (1965).

${ }^{7}$ Spira, D., and Zuckerman, A., Science, 137, 536 (1962).

${ }^{8}$ Voller, A., Ann. Soc. Belge Méd. Trop., 45, 385 (1965).

- Csizmas, L., Proc, Soc, Exp. Eiol. Med., 108, 157 (1960).

${ }^{10}$ Cole, L. R., and Farrell, V. R., J. Exp. Med., 102, 631 (1955). 